\title{
Social Entrepreneurship: Definition and Boundaries
}

\section{Samer Abu-Saifan}

\author{
"Whenever society is stuck or has an opportunity to seize a") \\ new opportunity, it needs an entrepreneur to see the \\ opportunity and then to turn that vision into a realistic \\ idea and then a reality and then, indeed, the new pattern \\ all across society. We need such entrepreneurial \\ leadership at least as much in education and human \\ rights as we do in communications and hotels. This is the \\ work of social entrepreneurs.
}

Bill Drayton

Founder of Ashoka: Innovators for the Public

\begin{abstract}
While individuals may be publicly recognized as social entrepreneurs for their contributions to improve the welfare of communities, the field of social entrepreneurship continues to struggle to gain academic legitimacy. Social entrepreneurship is a term in search of a good definition. The current use of the term seems vague and limitless; it needs boundaries to demarcate its function. The lack of a common definition hinders research and raises questions about which social or profit-making activities fall within the spectrum of social entrepreneurship. To become an important stream in the entrepreneurship literature, social entrepreneurship needs to be properly defined and it requires a theoretical framework that links it to the theory of entrepreneurship. This article builds on the literature to define social entrepreneurship, discusses the boundaries of socially-oriented entrepreneurial activities, and positions the social entrepreneur in the spectrum of entrepreneurship.
\end{abstract}

\section{Introduction}

Most economists and academics support the notion that entrepreneurship is becoming a crucial factor in the development and well-being of societies. Whether the entrepreneurial activities are practiced in factordriven, efficiency-driven, or innovation-driven economies (Porter et al., 2002; tinyurl.com/7vwutgr), the ultimate results continue to exhibit: i) lower unemployment rates; ii) increased tendency to adopt innovation; and iii) accelerated structural changes in the economy. Entrepreneurship offers new competition, and as such promotes improved productivity and healthy economic competitiveness (UNCTAD, 2004; tinyurl.com/d3xkdj4).

Social entrepreneurship is the field in which entrepreneurs tailor their activities to be directly tied with the ultimate goal of creating social value. In doing so, they often act with little or no intention to gain personal profit. A social entrepreneur "combines the passion of a social mission with an image of business-like discipline, innovation, and determination commonly associated with, for instance, the high-tech pioneers of Silicon Valley" (Dees, 1998; tinyurl.com/86g2a6).

The use of the term social entrepreneurship is gaining increased popularity. However, confusion and uncertainty are constantly noted about what exactly a social entrepreneur is and does. The term social entrepreneur is ill-defined (Barendsen and Gardner, 2004: tinyurl.com/75jr5sp; Weerawardena and Mort, 2006: tinyurl.com/7erg5lz), it is fragmented, and it has no coherent theoretical framework (Weerawardena and Mort, 2006). The absence of consensus on a research topic usually results in researchers working independently and failing to build upon one another's work, therefore knowledge cannot be accumulated (Bruyat and Julien, 2000; tinyurl.com/76ahqkm). 


\section{Social Entrepreneurship: Definition and Boundaries}

Samer Abu-Saifan

There is a need to better define what is meant by the term social entrepreneur. How are social entrepreneurs different from other entrepreneurs? How are social entrepreneurs different from managers of social workers? What constitutes social entrepreneurship and what does not?

In this article, we first review some of the literature discussing the definition of entrepreneurship and then provide a clear and concise definition of social entrepreneurship. Next, we identify the unique features of social entrepreneurs and suggest boundaries for social entrepreneurship.

\section{Characteristics of Entrepreneurship}

Social entrepreneurship needs to be defined in a way that is consistent with what is known about entrepreneurship. This section identifies the characteristics of the entrepreneur.

According to the business management literature, entrepreneurship is an exceptional set of activities carried out by individuals with an exceptional mind-set in order to maximize profit. Therefore, the process is closely tied to success. We use "exceptional mind-set" as a broader term to encapsulate the characteristics that shape the entrepreneurial activities of those individuals (see Table 1). The business literature differentiates entrepreneurs from business people by including statements such as: entrepreneurs "create needs"; while business people "satisfy needs" (2010 Global Report: Global Entrepreneurship Monitor, 2011; tinyurl.com/8xzvv3p). Entrepreneurs are conceptualized as individuals who see the world differently and envision the future better than others do. They seize opportunities that otherwise would go unnoticed. They perceive and accept risks differently than others. Table 1 shows the core characteristics of entrepreneurs, as extracted from full or partial definitions in the literature on venture creation, opportunity exploitation, and profit maximization. These characteristics highlight the economist's view of an entrepreneur as an individual with an exceptional mind-set; individuals with such a mind-set are seen as key to venture growth maximization and economic prosperity.

Table 1. Contrasting definitions and core characteristics of the terms "entrepreneur" and "entrepreneurship"

\begin{tabular}{|c|c|c|}
\hline Source & Definition & Core Characteristics \\
\hline $\begin{array}{l}\text { Schumpeter (1934) } \\
\text { tinyurl.com/6mqfkro }\end{array}$ & $\begin{array}{l}\text { An entrepreneur is an innovator who implements entrepreneurial change within } \\
\text { markets, where entrepreneurial change has five manifestations: 1) the } \\
\text { introduction of a new/improved good; 2) the introduction of a new method of } \\
\text { production; 3) the opening of a new market; } 4 \text { ) the exploitation of a new } \\
\text { source of supply; and 5) the carrying out of the new organization of any } \\
\text { industry }\end{array}$ & - Innovator \\
\hline $\begin{array}{l}\text { McClelland (1961) } \\
\text { tinyurl.com/6nsgtpd }\end{array}$ & $\begin{array}{l}\text { The entrepreneur is a person with a high need for achievement. This need for } \\
\text { achievement is directly related to the process of entrepreneurship [...] } \\
\text { Entrepreneur is an energetic moderate risk taker. }\end{array}$ & $\begin{array}{l}\text { - High achiever } \\
\text { - Risk bearer } \\
\text { - Dedicated }\end{array}$ \\
\hline $\begin{array}{l}\text { Kirzner (1978) } \\
\text { tinyurl.com/87mtxax }\end{array}$ & $\begin{array}{l}\text { The entrepreneur recognizes and acts upon market opportunities. The } \\
\text { entrepreneur is essentially an arbitrageur. }\end{array}$ & - Arbitrageur \\
\hline $\begin{array}{l}\text { Shapero }(1975) \\
\text { tinyurl.com/8xcuvj8 }\end{array}$ & $\begin{array}{l}\text { Entrepreneurs take initiative, organize some social and economic mechanisms } \\
\text { and accept risks of failure. }\end{array}$ & $\begin{array}{l}\text { - Organizer } \\
\text { - Initiative taker }\end{array}$ \\
\hline $\begin{array}{l}\text { Carland et al. (1984) } \\
\text { tinyurl.com/7xa9s7f }\end{array}$ & $\begin{array}{l}\text { The entrepreneur is characterised principally by innovative behaviour and will } \\
\text { employ strategic management practices in the business. }\end{array}$ & - Strategic thinker \\
\hline $\begin{array}{l}\text { Kao and Stevenson (1985) } \\
\text { tinyurl.com/6wcq6su }\end{array}$ & $\begin{array}{l}\text { Entrepreneurship is an attempt to create value through recognition of } \\
\text { business opportunities. }\end{array}$ & $\begin{array}{l}\text { - Value creator } \\
\text { - Opportunity aware }\end{array}$ \\
\hline $\begin{array}{l}\text { Timmons and Spinelli } \\
(2008) \\
\text { tinyurl.com/7sfqdh2 }\end{array}$ & $\begin{array}{l}\text { Entrepreneurship is a way of thinking, reasoning, and acting that is } \\
\text { opportunity obsessed, holistic in approach and leadership balanced. }\end{array}$ & $\begin{array}{l}\text { - Leader } \\
\text { - Holistic } \\
\text { - Persistent } \\
\text { - Committed }\end{array}$ \\
\hline
\end{tabular}




\section{Social Entrepreneurship: Definition and Boundaries}

Samer Abu-Saifan

\section{Characteristics of Social Entrepreneurship}

Although the use of the term social entrepreneur is growing rapidly, the field of social entrepreneurship lacks rigour and is in its infancy compared to the wider field of entrepreneurship. Success stories of individuals solving complex social problems are being used to legitimize the field of social entrepreneurship. For example, in 2004, Stanford University launched Social E Lab (socialelab.org) as part of its Entrepreneurial Design for Extreme Affordability course, which promotes the use of entrepreneurship principles to solve social and environmental problems. The program spun off a number of successful projects, including DripTech (driptech.com), Project Healthy Children (projecthealthychildren.org), and Embrace (embraceglobal.org). Other examples of well-established organizations that are frequently referenced in the literature on social entrepreneurship include: Ashoka (ashoka.org), OneWorld Health (oneworldhealth.org), The Skoll Foundation (skollfoundation.org), and the Schwab Foundation for Social Entrepreneurship (schwabfound.org). However, the field is arguably phenomenon-driven
(Mair and Martı', 2005; tinyurl.com/7ubxt5q) and falls short when compared to areas that are perceived to have greater rigour applied to them. As evidence of this, scholars have yet to link social entrepreneurship to the theory of entrepreneurship and knowledge.

The interest in social entrepreneurs stems from their role in addressing critical social problems and the dedication they show in improving the well-being of society (Zahra et al., 2008; tinyurl.com/87upzh3). The public often hold social entrepreneurs in high regard because of the multitude of social needs they satisfy and the improved life quality they bring to affected societies.

When comparing the definitions and characteristics of entrepreneurs (Table 1) with those of social entrepreneurs (Table 2), we see that the ultimate goal of an entrepreneur is to create economic wealth whereas, for a social entrepreneur, the priority is to fulfill their social mission. Social entrepreneurs design their revenue-generating strategies to directly serve their mission to deliver social value.

Table 2. Contrasting definitions and core characteristics of the terms "social entrepreneur" and "social entrepreneurship"

\begin{tabular}{|c|c|c|}
\hline Source & Definition & Core Characteristics \\
\hline $\begin{array}{l}\text { Bornstein (1998) } \\
\text { tinyurt.com:6ucfnc6 }\end{array}$ & $\begin{array}{l}\text { A social entrepreneur is a path breaker with a powerful new idea who } \\
\text { combines visionary and real-world problem-solving creativity, has a strong } \\
\text { ethical fiber, and is totally possessed by his or her vision for change. }\end{array}$ & $\begin{array}{l}\text { - Mission leader } \\
\text { - Persistent }\end{array}$ \\
\hline $\begin{array}{l}\text { Thompson et al. (2000) } \\
\text { tinyurl.com/7mkp } 7 \text { ah }\end{array}$ & $\begin{array}{l}\text { Social entrepreneurs are people who realize where there is an opportunity to } \\
\text { satisfy some unmet need that the state welfare system will not or cannot meet, } \\
\text { and who gather together the necessary resources (generally people, often } \\
\text { volunteers, money, and premises) and use these to "make a difference". }\end{array}$ & $\begin{array}{l}\text { - Emotionally charged } \\
\text { - Social value creator }\end{array}$ \\
\hline $\begin{array}{l}\text { Dees (1998) } \\
\text { tinyurl.com/86.9286 }\end{array}$ & $\begin{array}{l}\text { Social entrepreneurs play the role of change agents in the social sector by: } \\
\text { - Adopting a mission to create and sustain social value } \\
\text { - Recognizing and relentlessly pursuing new opportunities to serve that } \\
\text { mission; } \\
\text { - Engaging in a process of continuous innovation, adaptation, and learning; } \\
\text { - Acting boldly without being limited by resources currently in hand; } \\
\text { - Exhibiting a heightened sense of accountability to the constituencies } \\
\text { served for the outcomes created. }\end{array}$ & $\begin{array}{l}\text { - Change agent } \\
\text { - Highly accountable } \\
\text { - Dedicated } \\
\text { - Socially alert }\end{array}$ \\
\hline $\begin{array}{l}\text { Brinckerhoff (2009) } \\
\text { tinyurl.com/7w8df55 }\end{array}$ & $\begin{array}{l}\text { A social entrepreneur is someone who takes reasonable risk on behalf of the } \\
\text { people their organization serves. }\end{array}$ & - Opinion leader \\
\hline $\begin{array}{l}\text { Leadbeater (1997) } \\
\text { tinyurl.comi7exweb6 }\end{array}$ & $\begin{array}{l}\text { Social entrepreneurs are entrepreneurial, innovative, and "transformatory" } \\
\text { individuals who are also: leaders, storytellers, people managers, visionary } \\
\text { opportunists and alliance builders. They recognize a social problem and } \\
\text { organize, create, and manage a venture to make social change. }\end{array}$ & $\begin{array}{l}\text { - Manager } \\
\text { - Leader }\end{array}$ \\
\hline $\begin{array}{l}\text { Zahra et al. (2008) } \\
\text { tinyurl.com:87upzhi3 }\end{array}$ & $\begin{array}{l}\text { Social entrepreneurship encompasses the activities and processes undertaken } \\
\text { to discover, define, and exploit opportunities in order to enhance social wealth } \\
\text { by creating new ventures or managing existing organizations in an innovative } \\
\text { manner. }\end{array}$ & $\begin{array}{l}\text { - Innovator } \\
\text { - Initiative taker } \\
\text { - Opportunity alert }\end{array}$ \\
\hline $\begin{array}{l}\text { Ashoka (2012) } \\
\text { tinyurl.com/5jjvôu }\end{array}$ & $\begin{array}{l}\text { Social entrepreneurs are individuals with innovative solutions to society's most } \\
\text { pressing social problems [...] They are both visionaries and ultimate realists, } \\
\text { concerned with the practical implementation of their vision above all else. }\end{array}$ & $\begin{array}{l}\text { - Visionary } \\
\text { - Committed }\end{array}$ \\
\hline
\end{tabular}




\section{Social Entrepreneurship: Definition and Boundaries}

Samer Abu-Saifan

\section{Defining Social Entrepreneurship}

In this section, we build on the definitions presented in Table 2 and propose a definition that captures the key factors that are vital to social entrepreneurship. We hope that our definition will reduce the constantly perceived vagueness about the field, identify the scope of related research, and accelerate the advancement of social entrepreneurship as a legitimate academic research field.

We propose the following definition:

The social entrepreneur is a mission-driven individual who uses a set of entrepreneurial behaviours to deliver a social value to the less privileged, all through an entrepreneurially oriented entity that is financially independent, self-sufficient, or sustainable.

This definition combines four factors that make social entrepreneurship distinct from other forms of entrepreneurship. Social entrepreneurs:

1. are mission-driven. They are dedicated to serve their mission of delivering a social value to the underserved.
2. act entrepreneurially through a combination of characteristics that set them apart from other types of entrepreneurs (see Table 3 ).

3. act within entrepreneurially oriented organizations that have a strong culture of innovation and openness.

4. act within financially independent organizations that plan and execute earned-income strategies. The objective is to deliver the intended social value while remaining financially self-sufficient. This is achieved by blending social and profit-oriented activities to achieve self-sufficiency, reduce reliance on donations and government funding, and increase the potential of expanding the delivery of proposed social value (Bacq et al., 2011; tinyurl.com/7nry6jp).

Table 3 summarizes the unique characteristics of profit-oriented and social entrepreneurs presented in Tables 1 and 2 and identifies those characteristics that are most likely to be found in both types of entrepreneurs.

Table 3. Unique and common characteristics of profit-oriented entrepreneurs and social entrepreneurs

\begin{tabular}{|c|c|c|}
\hline $\begin{array}{l}\text { Unique characteristics of the } \\
\text { profit-oriented entrepreneur }\end{array}$ & $\begin{array}{l}\text { Characteristics common } \\
\text { to both types }\end{array}$ & $\begin{array}{l}\text { Unique characteristics of } \\
\text { the social entrepreneur }\end{array}$ \\
\hline $\begin{array}{ll}\text { - } & \text { High achiever } \\
\text { - } & \text { Risk bearer } \\
\text { - } & \text { Organizer } \\
\text { - } & \text { Strategic thinker } \\
\text { - } & \text { Value creator } \\
\text { - } & \text { Holistic } \\
\text { - } & \text { Arbitrageur }\end{array}$ & $\begin{array}{ll}\text { - } & \text { Innovator } \\
\text { - } & \text { Dedicated } \\
\text { - } & \text { Initiative taker } \\
\text { - } & \text { Leader } \\
\text { - } & \text { Opportunity alert } \\
\text { - } & \text { Persistent } \\
\text { - } & \text { Committed }\end{array}$ & $\begin{array}{ll}\text { - } & \text { Mission leader } \\
\text { - } & \text { Emotionally charged } \\
\text { - } & \text { Change agent } \\
\text { - } & \text { Social value creator } \\
\text { - } & \text { Socially alert } \\
\text { - } & \text { Manager } \\
\text { - } & \text { Visionary } \\
\text { - } & \text { Highly accountable }\end{array}$ \\
\hline
\end{tabular}




\section{Social Entrepreneurship: Definition and Boundaries}

Samer Abu-Saifan

\section{Boundaries of Social Entrepreneurship}

This section distinguishes between social entrepreneurship and other non-entrepreneurial, mission-driven initiatives. As discussed earlier, the term social entrepreneurship is becoming more popular and is attracting growing amount of resources. It is frequently observed in the media, used by public officials, and is commonly referred to by academics. This is in part because of the support social entrepreneurs are receiving from complex network of organizations that highlight their work and contributions to society (Dacin et al., 2011; tinyurl.com/ 7a9bh9d). However, the lack of consensus on the definition of social entrepreneurship means that other disciplines are often confused with and mistakenly associated with social entrepreneurship. Philanthropists, social activists, environmentalists, and other socially-oriented practitioners are referred to as social entrepreneurs. It is important to set the function of social entrepreneurship apart from other socially oriented activities and identify the boundaries within which social entrepreneurs operate.
According to the Skoll Centre for Social Entrepreneurship, the definition of social entrepreneurship should not extend to philanthropists, activists, companies with foundations, or organizations that are simply socially responsible (tinyurl.com/yd8ggyq). While all these agents are needed and valued, they are not social entrepreneurs.

Building on our proposed definition of social entrepreneurship, we propose boundaries to properly position social entrepreneurs in the spectrum of entrepreneurship. As illustrated in Figure 1, social entrepreneurs operate within the boundaries of two business strategies:

1. Non-profit with earned income strategies: a social enterprise performing hybrid social and commercial entrepreneurial activity to achieve self-sufficiency. In this scenario, a social entrepreneur operates an organization that is both social and commercial; revenues and profits generated are used only to further improve the delivery of social values.

\section{Non-Profit}

For-Profit

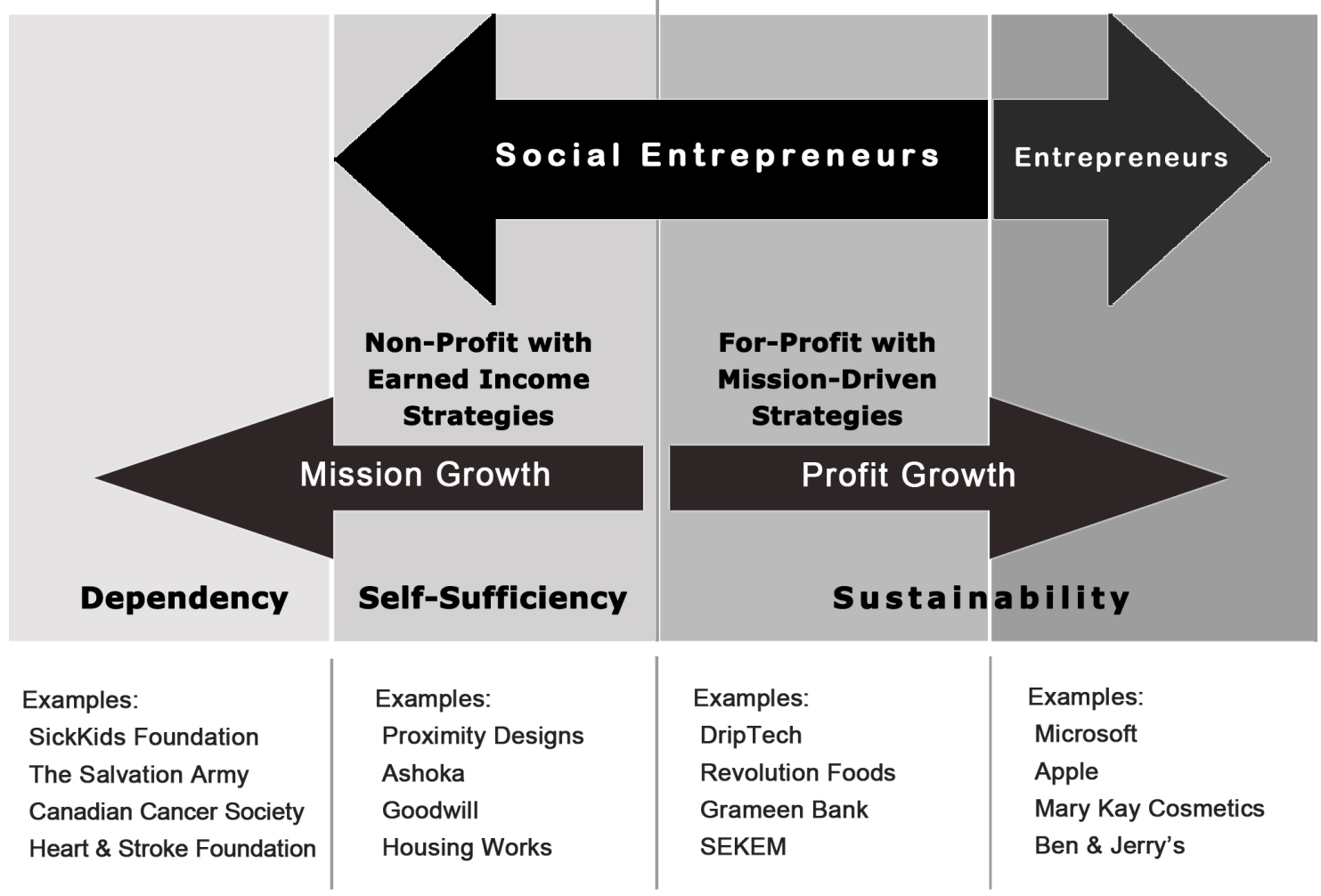

Figure 1. The entrepreneurship spectrum illustrating the boundaries of social entrepreneurship 


\section{Social Entrepreneurship: Definition and Boundaries}

Samer Abu-Saifan

2. For-profit with mission-driven strategies: a socialpurpose business performing social and commercial entrepreneurial activities simultaneously to achieve sustainability. In this scenario, a social entrepreneur operates an organization that is both social and commercial; the organization is financially independent and the founders and investors can benefit from personal monetary gain.

\section{Conclusion}

Social entrepreneurship has recently emerged as a field of academic inquiry, but the lack of a common definition of social entrepreneur impedes research in this field. In this article, we reviewed literature that defined profit-oriented entrepreneurship and social entrepreneurship in order to extract the core characteristics of each type. We then proposed a definition of social entrepreneurship, which contributes to the literature on social entrepreneurship by clarifying and bounding the scope of research in this field.

Social entrepreneurship has flourished significantly at the practical level, but not at the theoretical level. Future research should focus on linking social entrepreneurship as a new discipline and research field to the theory of entrepreneurship. Scholars should also focus their attention on introducing new research questions that are meaningful to the different domains that intersects with social entrepreneurship, including social innovation and the management of non-profit organizations.

\section{Recommended Reading}

The Rise of the Social Entrepreneur

by Charles Leadbeater

tinyurl.com/7exweb6

\section{About the Author}

Samer (Sam) Abu-Saifan is the Head of Information Technology for Street Haven at the Crossroads, a not-for-profit organization in Toronto. With over 15 years of experience managing complex technology environments, Sam has held positions in business development, change management, and innovation management. He received a BS in Computer Information Systems from Amman University, Jordan, and a Business Management Certificate from Ryerson University, Toronto. Currently, he is pursuing a Master's degree in Technology Innovation Management at Carleton University, Ottawa. In 2011, Sam founded Autism Ottawa (Ottism), a social purpose business that will use innovative technologies to deliver educational services to children and families living with autism.

Citation: Abu-Saifan, S. 2012. Social Entrepreneurship: Definition and Boundaries. Technology Innovation

(cc) BY 